\title{
Corrosion Behaviour of Metals in Artificial Tear Solution
}

\author{
C. Kumar ${ }^{1 *}$, A. John Amal Raj ${ }^{1}$ and S.K. Selvaraj ${ }^{2}$
}

${ }^{1} \mathrm{PG}$ and Research Department of Chemistry, Periyar E.V.R. College (Autonomous), Trichy-620023, Tamil

Nadu, India

Email: amalrajevr@gmail.com

${ }^{2}$ Corrosion Research Centre, PG and Research Department of Chemistry, GTN Arts College, Dindigul624005, Tamil Nadu, India

srisrielango@rediffmail.com

\begin{abstract}
Human tear comes in contact with a number of instruments during operation in the eyes. This results in a variety of undesirable effects such as corrosion and malfunction. Corrosion behaviour of five metals, namely, mild steel (MS), mild steel coated with zinc (MS-Zn), Ni-Cr, Ni-Ti super elastic (Ni-Ti.SE), and SS $316 \mathrm{~L}$ in artificial tear solution has been studied by polarization study and AC impedance spectra. The study reveals that the decreasing order of corrosion resistance in artificial tear solution is : Ni-Ti SE $>\mathrm{Ni}-\mathrm{Cr}>\mathrm{SS} 316 \mathrm{~L}>\mathrm{MS}-\mathrm{Zn}>\mathrm{MS}$. The first three metals are better candidates and the first one is the best candidate for making instruments used in operation in the eyes, in presence of tears.
\end{abstract}

Keywords: Corrosion of metals; artificial tear; Ni-Cr; SS 316 L

\section{Council for Innovative Research}

Peer Review Research Publishing System

Journal: Journal of Advances in Chemistry

Vol. 8, No. 3

editor@cirjac.com

www.cirjac.com, member.cirworld.com 


\section{Introduction}

Tears [1-18] are the liquid product of a process of crying to clean and lubricate the eyes. The word lacrimation (from L. Lacrima meaning tear) may also be used in a medical or literary sense to refer to crying. Strong emotions, such as sorrow or elation, may lead to crying. The process of yawning may also result in lacrimation.

In humans, the tear film coating the eyes, known as the precorneal film, has three different layers, from the most outer surface. They are lipid layer, aqueous layer and mucous layer.

Lipid layer : It contains oils, secreted by meibomian glands (or tarsal glameb). It coates the aqueous layer and provides a hydrophobic barrier that evaporates and prevents tears spilling onto the cheek.

Aqueous layer: It contains water and other substances such as protein (eg. Tear lipocalin, lacto ferrin and lacritin). It is secreed by lacrimal gland. It promotes spreading of the tear film. It also promotes osmotic regulations.

Mucous layer : It contains mucin. It is secreted by conjunctival goblet cells. It coats cornea; provides a hydrophilic layer; allows for even distribution of the tear films; covers the cornea.

There are three very basic types of tears. They are basal tears, reflex tears and crying or weeping (psychic tears).

During eye operations, the instruments come in contact with tears. Usually, the instruments are made of stainless steel or titanium alloys. These materials may under go corrosion when they come in contact with tears.

In the present work, the corrosion behaviour of metals in artificial tears (instead of tears) is investigated.

Artificial tears are lubricant eye drops used to treat the dryness and irritation associated with deficient tear production in keratoconjunctivitis sicca (dry eyes). They are also used to moisten contact lenses and in eye examinations.

Preparations of artificial tears contain carboxymethyl cellulose, hydroxypropyl methylcellulose and hydroxyl propyl cellulose. They contain water, salts and polymers but lack the proteins found in natural tears.

Review of literature reveals that much work has not been done in the field of corrosion behaviour of metals in natural/artificial tears.

The present work is undertaken, to study the corrosion behaviour of five metals, namely, mild steel (MS), mild steel coated with zinc (MS-Zn), Ni-Cr, Ni-Ti super elastic (SE) and SS $316 \mathrm{~L}$ in presence of artificial tear (AT) solution by polarization study and $A C$ impedance spectra. Corrosion parameters such as corrosion potential, corrosion current, linear polarization resistance, charge transfer resistance and double layer capacitance have been derived from these studies. Usually surgical instruments made of Ni-Cr, SS $316 \mathrm{~L}$ and Titanium are used for eye operations. The metals (MS, MS-Zn) which obviously undergo corrosion readily are chosen in this study just for comparison only.

\section{Experimental}

Five metals specimens, namely, mild steel (MS), mild steel coated with zinc (MS-Zn, commercial galvanized steel), Ni-Cr, $\mathrm{Ni}-\mathrm{Ti}$ super elastic and SS $316 \mathrm{~L}$ were chosen for the present study. MS and MS-Zn are chosen only for comparison. They can not be used during eye operations in presence of tears.

The composition of mild steel is (wt \%) : 0.26S, 0.06P, $0.4 \mathrm{Mn}, 0.1 \mathrm{C}$ and $5 \mathrm{ml}$ solution $+15 \mathrm{ml}$ of distilled water and balance iron [19].

The composition of SS $316 \mathrm{~L}$ is (wt \%): $18 \mathrm{Cr}, 12 \mathrm{Ni}, 2.5 \mathrm{Mo},<0.03 \mathrm{C}$ and balance iron [20].

The composition of $\mathrm{Ni}-\mathrm{Cr}$ is (wt \%) :

The composition of super elastic Ni-Ti alloy is (wt \%): $55 \mathrm{Ni}$ and $45 \mathrm{Ti}$ [21].

\section{Experimental}

\section{Potentiodynamic polarization study}

This study was carried out using $\mathrm{CHI} 660 \mathrm{~A}$ electrochemical impedance analyzer model. A three - electrode cell assembly was used. The working electrode used was carbon steel with $0.5 \mathrm{~cm}^{2}$ area exposed. A saturated calomel electrode (SCE) was used as reference electrode. A rectangular platinum foil was used as the counter electrode. Polarization curves were recorded after doing $i \mathrm{R}$ compensation. The parameters such as Tafel slopes, $\mathrm{I}_{\text {corr }}$ and $\mathrm{E}_{\text {corr }}$ were calculated.

\section{AC impedance measurements}

$\mathrm{CHI}$ 660A electrochemical impedance analyzer model was used to record AC impedance measurements. The cell set up was the same as that used for polarization measurements. The real part (Z') and imaginary part (Z") of the cell impedance were measured in ohms for various frequencies. The $\mathrm{R}_{\mathrm{t}}$ (charge transfer resistance) and $\mathrm{C}_{d l}$ (double layer capacitance) values were calculated. 


\section{Composition of artificial tear solution}

"Refresh Tears" (Lubricant eye drops) solution commercially available was used in the present study. Each $\mathrm{ml}$ of the solution contains

\begin{tabular}{|l|l|}
\hline Sodium Carboxymethyl Cellulose IP & $5 \mathrm{mg}$ \\
\hline Stabilised Oxychloro Complex (Purite) & $0.05 \mathrm{mg}$ \\
\hline Purified Water IP & q.s. \\
\hline
\end{tabular}

1 part of the eye drops was mixed with 3 parts of purified water and used in the present study. The solution prepared is referred to as artificial tear solution (ATS). Dilution is essential in this study, because undiluted "eye drops", when used in electrochemical studies, did not produce the desirable graphs.

\section{Results and Discussion}

\section{Potentiodynamic polarization study}

The potentiodynamic polarization curves of various metals (MS, MS-Zn, Ni-Cr, Ni-Ti super plastic and SS 316 L) immersed in artificial tears solution (ATS) are shown in Figs.1-5. The corrosion parameters, namely, corrosion potential $\left(E_{\text {corr }}\right)$, Tafel slopes $\left(b_{c}=\right.$ cathodic; $\left.b_{a}=a n o d i c\right)$, linear polarization resistance $(L P R)$ and corrosion current $\left(I_{\text {corr }}\right)$ are given in Table 1.

When mild steel (MS) is immersed in AT solution (Fig.1), the corrosion potential is $-620 \mathrm{mV}$ vs SCE. The cathodic Tafel slope $\left(b_{c}\right)$ is $248 \mathrm{mV} /$ decade and the anodic Tafel slope $\left(b_{a}\right)$ is $141 \mathrm{mV}$ vs SCE. It is inferred that the change of current with change in potential is less during anodic polarization than during cathodic polarization. Similar observation has been made during the study of corrosion behaviour of MS in artificial sweat solution [22]. In that case also the anodic Tafel slope was lesser ( $87 \mathrm{mV} /$ decade) than the cathodic Tafel slope (328 $\mathrm{mV} /$ decade). When MS in immersed in artificial tear solution, the linear polarization resistance (LPR) value is $121.54 \times 10^{2} \mathrm{ohm} \mathrm{\textrm {cm } ^ { 2 }}$ and the corrosion current is $3.22 \times 10^{-6}$ $\mathrm{A} / \mathrm{cm}^{2}$.

When mild steel coated with zinc (MS-Zn) is immersed in AT solution (Fig.2), the corrosion potential is shifted to the cathodic side (-684 $\mathrm{mV}$ vs SCE) (relative to MS). The cathodic and anodic Tafel slopes are almost equal (166 and 168 $\mathrm{mV} /$ decade, respectively). This indicates that the change of current during change of potential is more or less equal during cathodic and anodic polarization. Similar observation has been made when MS-Zn was immersed in artificial sweat solution [22]. The Tafel slopes were $b_{c}=128 \mathrm{mV} /$ decade and $b_{a}=126 \mathrm{mV} /$ decade in the case of artificial sweat solution.

When mild steel coated with zinc (MS-Zn) is immersed in AT solution, the LPR value increases from $121-54 \times 10^{2}$ (MS) to $1353.43 \times 10^{2} \mathrm{ohm} \mathrm{cm}^{2}$. The corrosion current decreases from $3.22 \times 10^{-6}$ to $2.68 \times 10^{-6} \mathrm{~A} / \mathrm{cm}^{2}$. These results suggest that mild steel coated with zinc is more corrosion resistant than mild steel. This is due to the cathode protective nature of zinc. Zinc undergoes corrosion, protecting mild steel. Zinc is often referred to as sacrificial anode [23]

When $\mathrm{Ni}-\mathrm{Cr}$ is immersed in AT solution, the corrosion potential is shifted to $-506 \mathrm{mV}$ vs SCE (Fig.3). This is anodic (noble) when compared with mild steel and also mild steel coated with zinc. Thus it is observed that Ni-Cr is more corrosion resistant than MS and MS-Zn. This view is supported by the fact that the LPR value is $121611.96 \times 10^{2}$ ohm $\mathrm{cm}^{2}$, when Ni-Cr is immersed in AT solution. This value is higher when compared with the LPR values of MS and MS-Zn. This is further supported by the fact that the corrosion current value, $3.35 \times 10^{-9} \mathrm{~A} / \mathrm{cm}^{2}$, is very much lower than the values of MS and MS-Zn. An increase in LPR value and a decrease in corrosion current value are indications of more corrosion resistant nature of a metal in a medium [22].

When $\mathrm{Ni}$-Ti super elastic (SE) is immersed in AT solution, the corrosion potential is shifted to $-436 \mathrm{mV}$ vs SCE (Fig.4). It is anodic (noble) when compared with mild steel. That is Ni-Ti SE is more corrosion resistant than MS, MS-Zn and even $\mathrm{Ni}-\mathrm{Cr}$. This view is further supported by the fact that the LPR value is $271280.44 \times 10^{2} \mathrm{ohm} \mathrm{cm}^{2}$, when Ni-Ti SE is immersed in AT solution. This value is much higher when compared with the value of MS, MS- $\mathrm{Zn}$ and $\mathrm{Ni}-\mathrm{Cr}$. This is further supported by the corrosion current value, $\left(1.58 \times 10^{-9} \mathrm{~A} / \mathrm{cm}^{2}\right)$, which is lower than that of MS, MS-Zn and Ni-Cr.

When SS $316 \mathrm{~L}$ is immersed in AT solution, the corrosion potential is shifted to $-321 \mathrm{mV}$ vs SCE (Fig.5). It is anodic (noble) when compared with mild steel and also with other metals. When compared with the values of mild steel, there is increase in LPR value and decrease in corrosion current. It is inferred that SS $316 \mathrm{~L}$ is more corrosion resistant than MS.

Thus, polarization study leads to the conclusion that the order of the corrosion resistance of the metals under investigation is :

$\mathrm{Ni}-\mathrm{Ti}$ SE $>\mathrm{Ni}-\mathrm{Cr}>\mathrm{SS} 316 \mathrm{~L}>\mathrm{MS}-\mathrm{Zn}>\mathrm{MS}$

\section{AC impedance spectra}

AC impedance spectra of metals immersed in artificial tear (AT) solution are shown in Figs.6-20. Nyquist plots are shown in Figs.6-10; the bode plots are shown in Figs.11-20. The charge transfer resistance $\left(R_{t}\right)$ and double layer capacitance 
$\left(C_{d l}\right)$ values (derived from Nyquist plots and the impedance, log $(z / o h m)$, values derived from Bode plots are given in Table 2.

When mild steel is immersed in AT solution, the charge transfer resistance is $836 \mathrm{ohm} \mathrm{cm}^{2}$ and the double layer capacitance is $6.100 \times 10^{-9} \mathrm{~F} / \mathrm{cm}^{2}$ (Fig.6). The impedance, log (z/ohm), value is 2.827 (Fig.11).

When mild steel coated with zinc is immersed in AT solution, the charge transfer resistance decreases from 836 to 436 $\mathrm{ohm} \mathrm{cm}^{2}$ (Fig.7). The double layer capacitance value increases from $6.100 \times 10^{-9}$ to $1.170 \times 10^{8} \mathrm{~F} / \mathrm{cm}^{2}$. The impedance, $\log$ (z/ohm), value decreases from 2.827 to 2.607 (Fig.12). These results suggest that MS-Zn is less corrosion resistant than MS. This contrary to the result derived from polarization study. This can be explained by the fact, that, the film formed on the surface of MS-Zn is amorphous and porous in nature and allows electron transfer from metal surface to the solution phase. Hence, charge transfer resistance decreases and double layer capacitance increases; the impedance value, $\log (\mathrm{z} / \mathrm{ohm})$, decreases. The study on the corrosion behaviour of metals in artificial sweat, using AC impedance spectra [22] also reveals that MS-Zn is less corrosion resistant than MS, due to similar reason.

When $\mathrm{Ni}-\mathrm{Cr}$ is immersed in AT solution, the charge transfer resistance is very high $224.3 \times 10^{3} \mathrm{ohm} \mathrm{cm}^{2}$ (Fig.8). The double layer capacitance is low $2.274 \times 10^{-11}$. The impedance, $\log (\mathrm{z} / \mathrm{ohm})$, is 6.108 (Fig.13). It is inferred that $\mathrm{Ni}-\mathrm{Cr}$ is more corrosion resistant than MS and MS-Zn. This conclusion is in agreement with the result derived from polarization study.

When $\mathrm{Ni}$-Ti super elastic is immersed in AT solution, the charge transfer resistance is very high $1493 \times 10^{3}$ (Fig.9) and the double layer capacitance is very low, $3.416 \times 10^{-12} \mathrm{~F} / \mathrm{cm}^{2}$; the impedance, log (z/ohm), value is high, 6.235 (Fig.14). These results suggest that $\mathrm{Ni}-\mathrm{Ti}$ super elastic is more corrosion resistant in AT solution than MS, MS-Zn and Ni-Cr.

When SS $316 \mathrm{~L}$ is immersed in AT solution, $371.5 \times 10^{3} \mathrm{ohm} \mathrm{cm}^{2}$ (Fig.10) and the double layer capacitance is $1.373 \times 10$ ${ }^{11} \mathrm{~F} / \mathrm{cm}^{2}$. The impedance, $\log (\mathrm{z} / \mathrm{ohm})$, value is 5.888 (Fig.15). This indicates that the corrosion resistance of SS $316 \mathrm{~L}$ in AT solution is better than that of $\mathrm{Ni}-\mathrm{Cr}$. But this result is contrary to that derived from polarization study, that is, Ni-Cr is more corrosion resistant than SS $316 \mathrm{~L}$. The conclusion derived from AC impedance spectra can be explained by the fact that the film formed on the metal surface (SS $316 \mathrm{~L}$ ) is more compact and close packed.

The AC impedance spectra lead to the conclusion that the decreasing order of corrosion resistance of metals in artificial tear solution is

$\mathrm{Ni}$-Ti super elastic $>\mathrm{SS} 316 \mathrm{~L}>\mathrm{Ni}-\mathrm{Cr}>\mathrm{MS}>\mathrm{MS}-\mathrm{Zn}$

The difference in conclusion derived from polarization study and AC impedance spectra may be attributed to the fact that $\mathrm{AC}$ impedance spectra reveal that the close -packedness and compactness of the protective film formed on the metal surface is in the order mentioned above.

The corrosion behaviour of the protective films appears to be governed by a complex interrelated ensemble of chemical, structural, textural, morphological and electronic characteristics of the films.

\section{Analysis of Bode plots}

There are two types of Bode plots. In the first type $\log (\mathrm{Freq} / \mathrm{Hz})$ is plotted against $\log (\mathrm{z} / \mathrm{ohm})$. In the second type log $($ Freq/Hz) is plotted against -Phase/degree. They are called Impedance bode plot and phase bode plot respectively. They give valuable information regarding impedance value and phase angle value.

\section{Impedance bode plots}

The impedance bode plots of various metals in artificial tear (AT) solutions are shown in Figs. 11 to 15.

\section{MS immersed in AT solution}

When MS is immersed in AT solution (Fig.11), the impedance value, log (z/ohm), is 2.825, when log (Freq/Hz) value is 0.0 . As the value of $\log (\mathrm{Freq} / \mathrm{Hz})$ increases from 0 to 2 , the impedance value increases steadily. A maximum of 3.08 is obtained when frequency is 4.052 . Then this value slowly decreases to 2.742 when frequency value is 5.0 .

\section{MS-Zn immersed in AT solution}

When MS-Zn is immersed in AT solution (Fig.12), the impedance value is 2.604 , when the frequency is 0.00 . When the frequency increases from zero to 2, the impedance value increases sharply and reaches a maximum value of 2.817 when frequency is 4.026 . Then it slowly decreases and reaches a minimum of 2.466 when frequency is 5.0 .

\section{$\mathrm{Ni}-\mathrm{Cr}$ immersed in AT solution}

When $\mathrm{Ni}-\mathrm{Cr}$ is immersed in AT solution (Fig.13), the impedance value is 6.108, corresponding to zero frequency. When frequency increases from zero to 3 , the impedance value decreases rapidly and then decreases slowly. It reaches a minimum of 3.103 when frequency is 5 . 


\section{$\mathrm{Ni}-\mathrm{Ti}$ super elastic}

When Ni-Ti SE is immersed in AT solution (Fig.14), the impedance value is 6.235, when the frequency is 0.1113 . When frequency increases from 0.1113 to 3 , the impedance value decreases sharply; then it decreases slowly to 2.912 at frequency of 5.0 .

\section{SS $316 \mathrm{~L}$ immersed in AT solution}

When SS $316 \mathrm{~L}$ is immersed in AT solution (Fig.15), the impedance value is 5.912 , when the frequency is 0.15 . When frequency increases from zero to 3 , the impedance value sharply decreases and then slowly decreases to 3.081 when the frequency is 5.0 .

\section{Phase bode plots, log (Freq/Hz) vs -Phase/deg. MS immersed in AT solution}

The phase bode plot of MS immersed in AT solution is shown in Fig.16. When log (Freq/Hz) value is zero, the -Phase/deg value is also zero. This value remains constant when the frequency increases from 0 to 1.5 . Then the value slowly increases upto frequency 3.5. Further increase in frequency results in sharp increase in -phase/deg value. When frequency is 50 the -phase/deg value is high, namely, 53.44 .

\section{MS-Zn immersed in AT solution}

The phase bode plot of MS-Zn immersed in AT solution is shown in Fig.17. When frequency is zero, the -phase/deg value is also zero. This value remains at zero when frequency increases from 0 to 1.5. The -phase/deg value slowly increases when frequency is increased from 1.5 to 3.5. Further increase in frequency results sharp increase in -phase/deg value. A maximum of 45 is obtained at 5.0 .

\section{$\mathrm{Ni}-\mathrm{Cr}$ immersed in AT solution}

The phase bode plot of $\mathrm{Ni}-\mathrm{Cr}$ immersed in AT solution is shown in Fig.18. When frequency is zero, the -phase/deg value is very high, 80 . This value slowly decreases, as the frequency increases, and declines to a minimum of 23.38 when the frequency is 3.921. Then the -phase/deg value increases to 48.00 when frequency is 5.0 .

\section{$\mathrm{Ni}$-Ti super elastic immersed in AT solution}

The phase bode plot of Ni-Ti SE immersed in AT solution is shown in Fig.19. When frequency is 0.1113 , the -phase/deg value is 75.63. This value remains constant, when the frequency is increased from 0 to 1.5 . Then the value slowly decreases to a minimum of 30.94 at frequency of 4.0 . Then this value increases to 48.13 at frequency 5.0.

\section{SS $316 \mathrm{~L}$ immersed in AT solution}

The phase bode plot of SS $316 \mathrm{~L}$ immersed in AT solution is shown in Fig.20. When frequency is 0.1173, the -phase/deg value is 60.35 . This value slowly increases and reaches a maximum of 67.38 at a frequency of 1.163 . Then the value decreases, reaches a minimum of 25.00 at a frequency of 38.76. Then this value increases to 47.60 at frequency 5.0.

Analysis of the $\log (\mathrm{Freq} / \mathrm{Hz})$ vs $\log (\mathrm{z} / \mathrm{ohm})$ plots is summarized in Table 3. Analysis of the $\log (\mathrm{Freq} / \mathrm{Hz})$ vs $-\mathrm{Phase} / \mathrm{deg}$ plots is summarized in Table 4.

\section{Conclusion}

- Corrosion behaviour of five metals, namely, mild steel, mild steel coated with zinc, Ni-Cr, Ni-Ti super elastic and SS $316 \mathrm{~L}$ in artificial tear solution has been evaluated by polarization study and AC impedance spectra.

- Polarization study reveals that corrosion resistance of the metals studied in artificial tear solution is in the decreasing order:

$$
\mathrm{Ni}-\mathrm{Ti} \mathrm{SE}>\mathrm{Ni}-\mathrm{Cr}>\mathrm{SS} 316 \mathrm{~L}>\mathrm{MS}-\mathrm{Zn}>\mathrm{MS}
$$

- $\mathrm{AC}$ impedance spectra reveal that the corrosion resistance of the metals in artificial tear solution is in the decreasing order:

$$
\mathrm{Ni} \text {-Ti super elastic }>\mathrm{SS} 316 \mathrm{~L}>\mathrm{Ni}-\mathrm{Cr}>\mathrm{MS}>\mathrm{MS}-\mathrm{Zn}
$$

- $\quad A C$ impedance spectra also reveal that the close-packedness and compactness of the protective films formed on the metal surface is in the decreasing order :

$$
\text { Ni-Ti super elastic > SS } 316 \mathrm{~L}>\mathrm{Ni}-\mathrm{Cr}>\mathrm{MS}>\mathrm{MS}-\mathrm{Zn}
$$


- $\quad \mathrm{Ni}$-Ti super elastic, $\mathrm{Ni}-\mathrm{Cr}$ and SS $316 \mathrm{~L}$ are the better candidates to make surgical instruments which come in contact with tears, especially, during eye operations.

- $\mathrm{Ni}$-Ti super elastic is the best candidate.

\section{Acknowledgement}

The authors are thankful to their managements and UGC, India, for their help and encouragement. Mr. S. Elango for his computer aided design and help.

Table 1 : Corrosion parameters of metals immersed in artificial tear solution (ATS) obtained from polarization study

\begin{tabular}{|c|c|c|c|c|c|}
\hline Metal & $\begin{array}{c}E_{\text {corr }} \\
m V \text { vs SCE }\end{array}$ & $\begin{array}{c}\mathrm{b}_{\mathrm{c}} \\
\mathrm{mV} / \mathrm{dec} \text { ede }\end{array}$ & $\begin{array}{c}\mathrm{b}_{\mathrm{a}} \\
\mathrm{mV} / \mathrm{dec} \text { ecade }\end{array}$ & $\begin{array}{c}\text { LPR } \\
\text { ohm cm² }\end{array}$ & $I_{\text {corr }} \quad \mathrm{A} / \mathrm{cm}^{2}$ \\
\hline MS & -620 & 248 & 141 & $121.54 \times 10^{2}$ & $3.22 \times 10^{-6}$ \\
\hline MS-Zn & -684 & 166 & 168 & $1353.43 \times 10^{2}$ & $2.68 \times 10^{-6}$ \\
\hline $\mathrm{Ni}-\mathrm{Cr}$ & -506 & 142 & 274 & $121611.96 \times 10^{2}$ & $3.35 \times 10^{-9}$ \\
\hline Ni-Cr Super Plastic & -436 & 153 & 279 & $271260.44 \times 10^{2}$ & $1.58 \times 10^{-9}$ \\
\hline SS $316 \mathrm{~L}$ & -321 & 173 & 295 & $13806.50 \times 10^{2}$ & $3.43 \times 10^{-8}$ \\
\hline
\end{tabular}

Table 2 : Corrosion parameters of metals immersed in artificial tear solution obtained from AC impedance spectral study

\begin{tabular}{|c|c|c|c|}
\hline \multirow[b]{2}{*}{ Metal } & \multicolumn{2}{|c|}{ Nyquist plot } & Bode plot \\
\hline & $\mathrm{R}_{\mathrm{t}} \mathrm{cm}^{2}$ & $\mathrm{C}_{\mathrm{dl}} \quad \mathrm{F} / \mathrm{cm}^{2}$ & $\begin{array}{l}\text { Impedance, } \\
\text { log (z/ohm) }\end{array}$ \\
\hline MS & 836 & $6.100 \times 10^{-9}$ & 2.827 \\
\hline MS-Zn & 436 & $1.170 \times 10^{8}$ & 2.607 \\
\hline $\mathrm{Ni}-\mathrm{Cr}$ & $224.3 \times 10^{3}$ & $2.274 \times 10^{-11}$ & 6.108 \\
\hline Ni-Ti Super elastic & $1493 \times 10^{3}$ & $3.416 \times 10^{-12}$ & 6.235 \\
\hline SS 316 L & $371.5 \times 10^{3}$ & $1.373 \times 10^{-11}$ & 5.888 \\
\hline
\end{tabular}


Table 3 : Analysis of $\log (\mathrm{Freq} / \mathrm{Hz})$ vs $\log (\mathrm{z} / \mathrm{ohm})$ plots when metals are immersed in artificial tear solution

\begin{tabular}{|c|c|c|c|}
\hline Metal & Figure No. & $\log ($ Freq/Hz) & $\log (\mathrm{z} / \mathrm{ohm})$ \\
\hline \multirow{4}{*}{$\stackrel{\infty}{\Sigma}$} & \multirow{4}{*}{11} & 0 & 2.825 \\
\hline & & 5 & 2.742 \\
\hline & & 4.052 & 3.08 (Maximum) \\
\hline & & 0 to 2 & increases sharply \\
\hline \multirow{4}{*}{$\begin{array}{l}\text { N } \\
\text { ஸे } \\
\sum\end{array}$} & \multirow{4}{*}{12} & 0 & 2.604 \\
\hline & & 5 & 2.466 \\
\hline & & 4.046 & 2.817 (Maximum) \\
\hline & & 0 to 2 & increases sharply \\
\hline \multirow{4}{*}{$\frac{\grave{U}}{\frac{1}{z}}$} & \multirow{4}{*}{13} & 0 & 6.108 \\
\hline & & 5 & 3.103 \\
\hline & & 0 to 3 & decreases sharply \\
\hline & & after 3 & decreases slowly \\
\hline \multirow{4}{*}{ 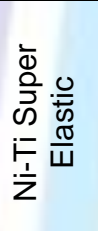 } & \multirow{4}{*}{14} & 0.1113 & 6.235 \\
\hline & & 5 & 2.912 \\
\hline & & 0.1113 to 3 & decreases sharply \\
\hline & & after 3 & decreases slowly \\
\hline \multirow{4}{*}{$\begin{array}{l}\vec{\omega} \\
\stackrel{\infty}{\infty} \\
\stackrel{\omega}{ }\end{array}$} & \multirow{4}{*}{15} & 0.1500 & 5.912 \\
\hline & & 5 & 3.081 \\
\hline & & 0 to 3 & decreases sharply \\
\hline & & after 3 & decreases slowly \\
\hline
\end{tabular}

Table 4 : Analysis of log $(\mathrm{Freq} / \mathrm{Hz})$ vs -Phase/deg plots, when metals are immersed in artificial tear solution

\begin{tabular}{|c|c|c|c|}
\hline Metal & Figure No. & $\log ($ Freq/Hz) & -Phase/deg \\
\hline \multirow{5}{*}{$\stackrel{\infty}{\Sigma}$} & \multirow{5}{*}{16} & 0 to 1.5 & zero \\
\hline & & 1.5 to 3 & slowly increases \\
\hline & & after 3 & sharply increases \\
\hline & & 5 & 53.44 \\
\hline & & 0 & zero \\
\hline \multirow{5}{*}{$\begin{array}{l}\text { N } \\
\text { ஸे } \\
\sum\end{array}$} & \multirow{5}{*}{17} & 0 to 1.5 & zero \\
\hline & & 1.5 to 3.5 & slowly increases \\
\hline & & after 3.5 & sharply increases \\
\hline & & 5.0 & 45 \\
\hline & & 0 & zero \\
\hline \multirow{4}{*}{$\frac{\grave{1}}{\frac{1}{Z}}$} & \multirow{4}{*}{18} & 0 & 80 \\
\hline & & after 0 & slowly decreases \\
\hline & & 3.921 & 23.38 (minimum) \\
\hline & & after 3.921 & increases \\
\hline
\end{tabular}




\begin{tabular}{|c|c|c|c|}
\hline & & 5.0 & 48.00 \\
\hline \multirow{6}{*}{ 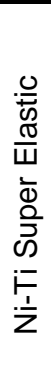 } & \multirow{6}{*}{19} & 0.1113 & 75.63 \\
\hline & & 0.1113 to 1.5 & $\begin{array}{c}\text { remains constant } \\
(75.63)\end{array}$ \\
\hline & & after 1.5 & slowly decreases \\
\hline & & 4.0 & 30.94 (minimum) \\
\hline & & after 4.0 & increases \\
\hline & & 5.0 & 48.13 \\
\hline \multirow{7}{*}{$\begin{array}{l}\frac{1}{\omega} \\
\frac{n}{\infty} \\
\infty\end{array}$} & \multirow{7}{*}{20} & 0.1173 & 60.35 \\
\hline & & after 0.1173 & slowly increases \\
\hline & & 1.163 & 67.38 (maximum) \\
\hline & & after 1.163 & decreases \\
\hline & & 3.876 & 25.00 \\
\hline & & after 3.876 & increases \\
\hline & & 5.0 & 47.60 \\
\hline
\end{tabular}

\section{References}

[1] "Eye, human. "Encyclopaedia Britannica from Encyclopaedia Britannica 2006, Ultimate Reference Suite DVD 2009.

[2] Ocular Pathology Study Guide: Tear Proteins

[3] A. Skorucak, "The science of tears", Science IQ.com. Accessed September 29, 2006.

[4] D.H. Szczesna, J.Jaronski, H.T. Kasprzak, U. Stenevi, "Interferometric measurements of dynamic changes of tear film", J. Biomed Opt. 2006, May-Jun; 11(3), 34028. PMID 16822077.

[5] Corcodile tears syndrome, Acta Otorrinolaringol Esp. 1990 May-Jun, PubMed Result

[6] B. Felicia Axelrod and Gabrielle Gold-Von Simson (October 3, 2007). "Hereditary sensory and autonomic neuropathies: types II, III, and IV", Orphanet Journal of Rare Diseases, 2 (39): 39: DOI : 10.1186/1750-1172-2-39. PMID 17915006. PMC 2098750. http://www.ojrd.com/content

[7] Masso, Jeffrey Moussaieff, McCarthy, Susan, When Elephants Weep, Delta 1996 isbn:9780385314282

[8] 8. Dianne Hales (October 2005). "Big oys Don't Cry - and Other Myths About Men and Their Emotions (page 2 of 3)". Reader's Digest. http://www.rd.com/living-healthy/big-boys-dont-cry-andother-myths-about-men-and-their-emotions/article18503-1.html.

[9] Fran Metcalf (May 8, 2008). "These days it's OK for men to cry, say famous guys". The Courier Mail. http://www.news.com.au/couriermail/story/0,23739,23660131-23272,00.html.

[10] John-Paul Flintoff (August 30,2003). "Why we cry". The Age. http://www.theage.com.au/articles/2003/08/27/1061663846142.html.

[11] Re-evaluation Counseling site: "The Recovery Process"

[12] World Wide Words: Crocodile tears

[13] Keratoconjunctivities, Sicca". eMedicine. WebMD. Inc., 2006-04-21. http://www.emedicine.com/oph/topic695.htm. retrieved 2006-11-12.

[14] Meadows. Michelle (May-June 2005). "Dealing with Dry Eye". FDA Consumer Magazine. U.S. Fodd and Drug Administration, http://www.fda.gov/fdac/features/2005/305_eye.html.

[15] 15. "Keratoconjunctivitis Sicca". The Merck Manual. Home Edition. Merck \& Co., Inc., 2003-02-01. http://www.merck.com/mmhe/sec20/ch230/ch230d.html. 
[16] Lacrisert [prescribing information]. Lawrenceville, NJ: Aton Pharma, Inc; 2007

[17] Katz JI. Kaufman HE, Breslin C, Katz IM. Slow-release artificial tears and the treatment of keratitis sicca. Ophthalmology. 1978;85(8):787-793.

[18] Keratoconjunctivitis, Sicca”. The Merck Veterinary Manual. Merck \& Co., Inc. http://www.merckvetmanual.com/mvm/index.jsp?cfile=htm/bc/30107.htm.

[19] J. Arockia Selvi, S. Rajendran, V. Ganga Sree, A. John Amal Raj and B. Narayanasamy, "Corrosion inhibition by beet root extract", Portugaliae Electrochimica Acta, 27 (2009) 1-11.

[20] I. Guruppa, Characteristics of different materials for corrosion resistance under simulated body fluid conditions, Mater. Character., 49 (2002) 73-79.

[21] Gurmeerat Singh, Materials used in Orthodontico - Introduction and Archwire Materials - Text Book of Orthodontics, p.302.

[22] R. Joseph Rathish, S. Rajendran, J. Lydia Christy, B. Shyamala Devi, S. John Mary, M. Manivannan, K. Rajam and P. Rengan, "Corrosion behaviour of metals in artificial sweat", The Open Corrosion Journal, 3 (2010) 38-44.

[23] M.G. Fontana, Corrosion Engineering, $3^{\text {rd }}$ ed., New Delhi, Tata McGraw-Hills, 2005, p.298.

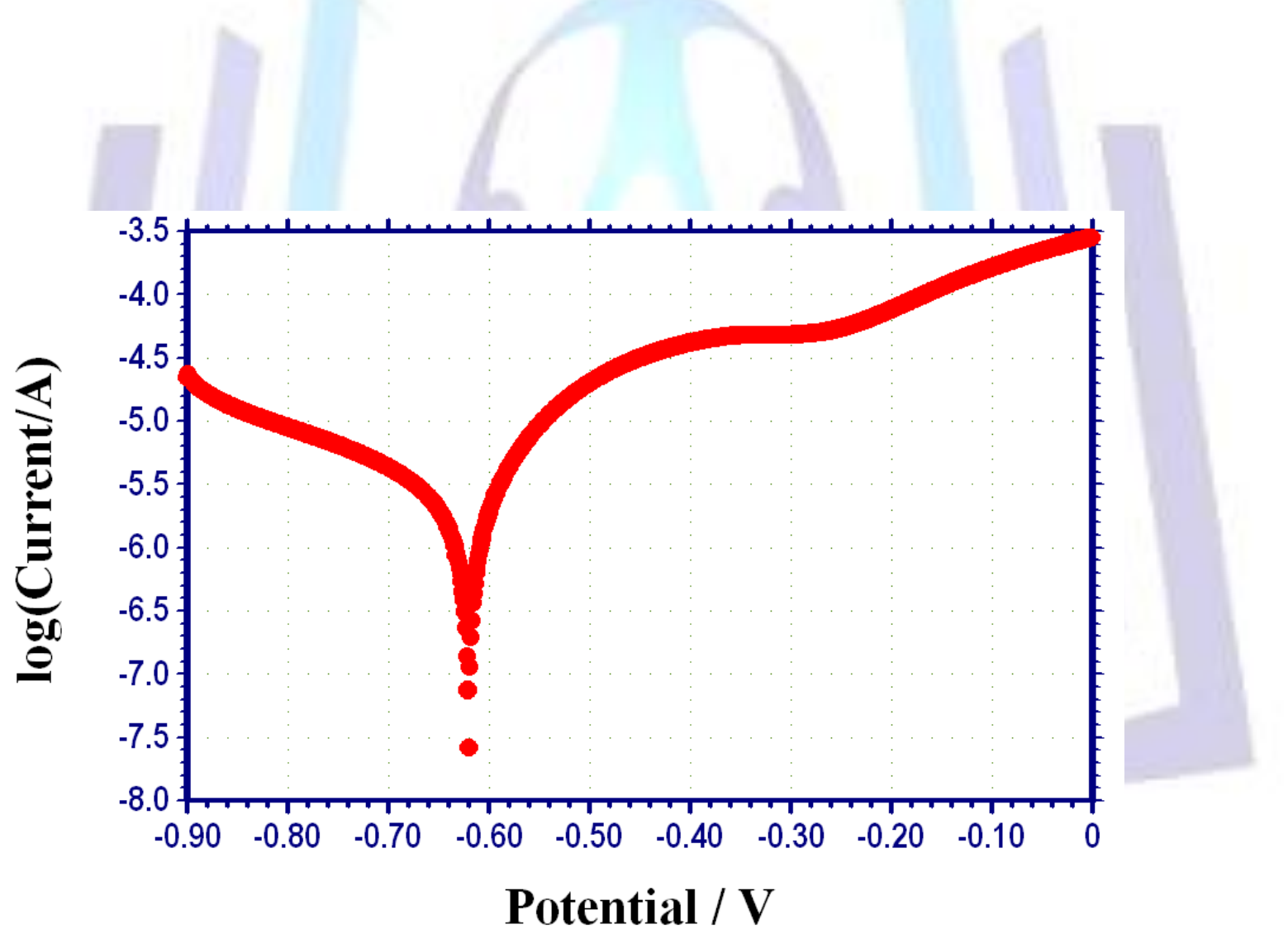

Fig.1: Polarization curve of MS in artificial tear solution 

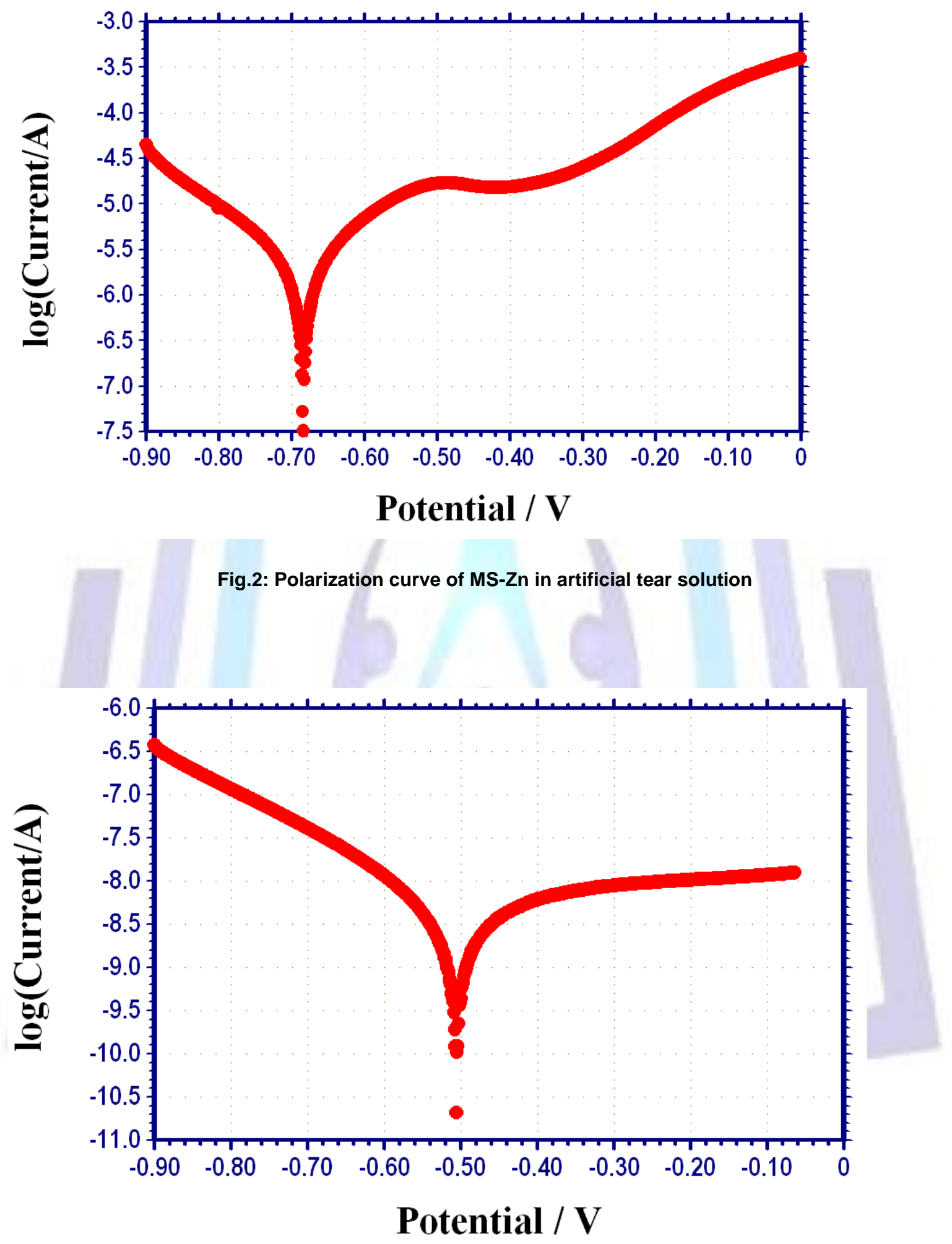

Fig.3: Polarization curve of $\mathrm{Ni}-\mathrm{Cr}$ in artificial tear solution 


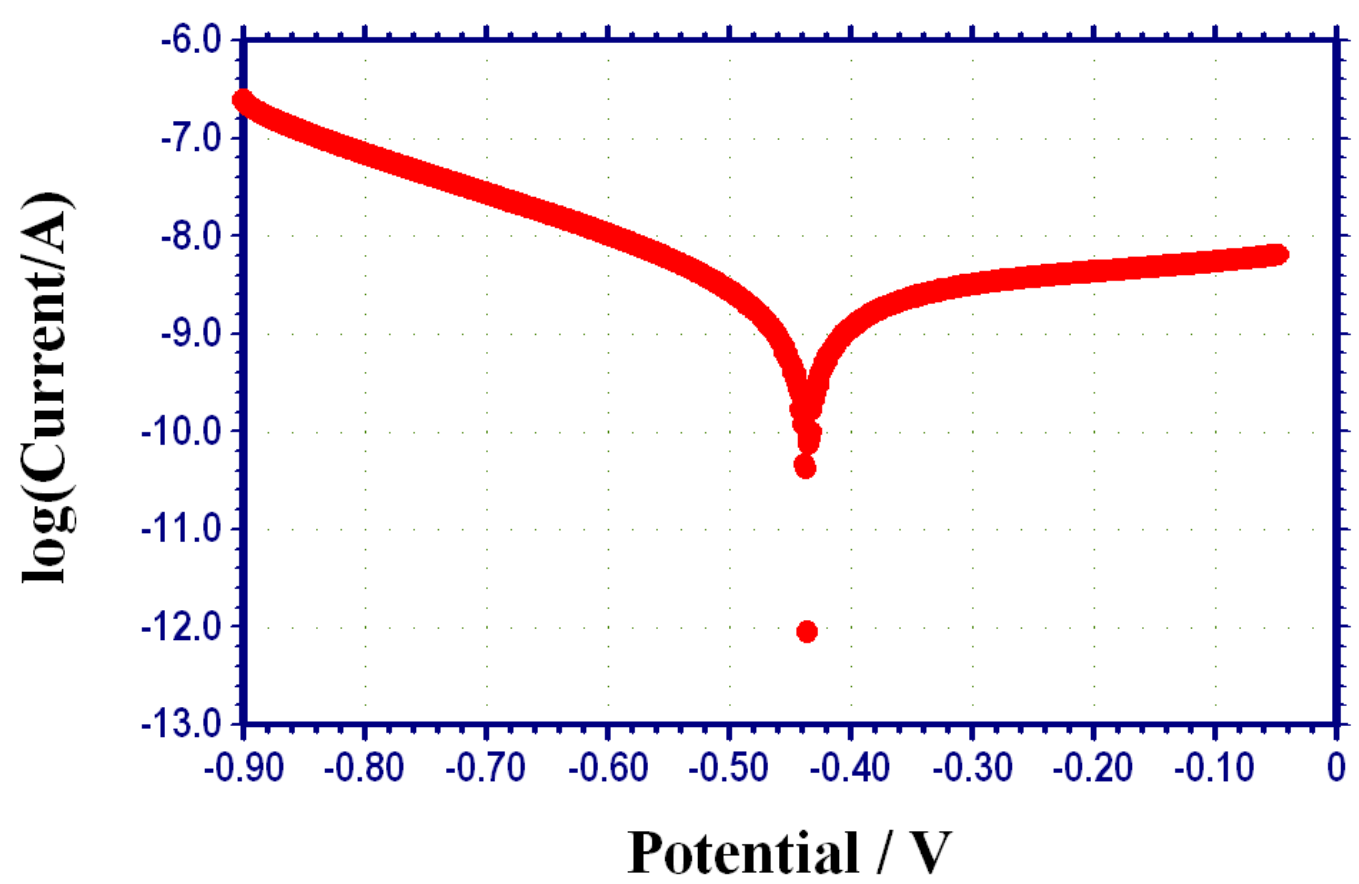

Fig.4: Polarization curve of $\mathrm{Ni}-\mathrm{Ti}$ super elastic in artificial tear solution

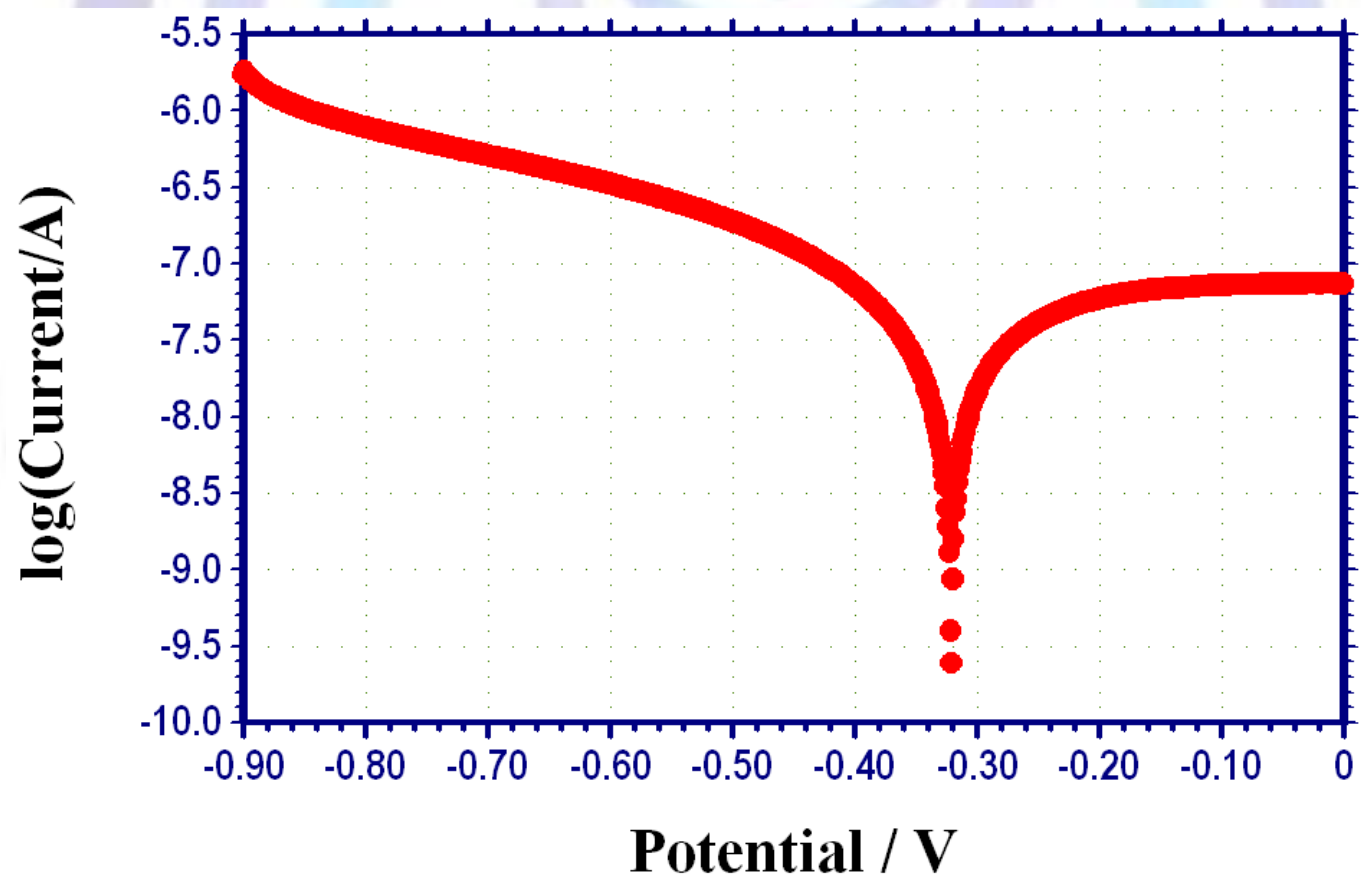

Fig.5: Polarization curve of SS $316 \mathrm{~L}$ super elastic in artificial tear solution 


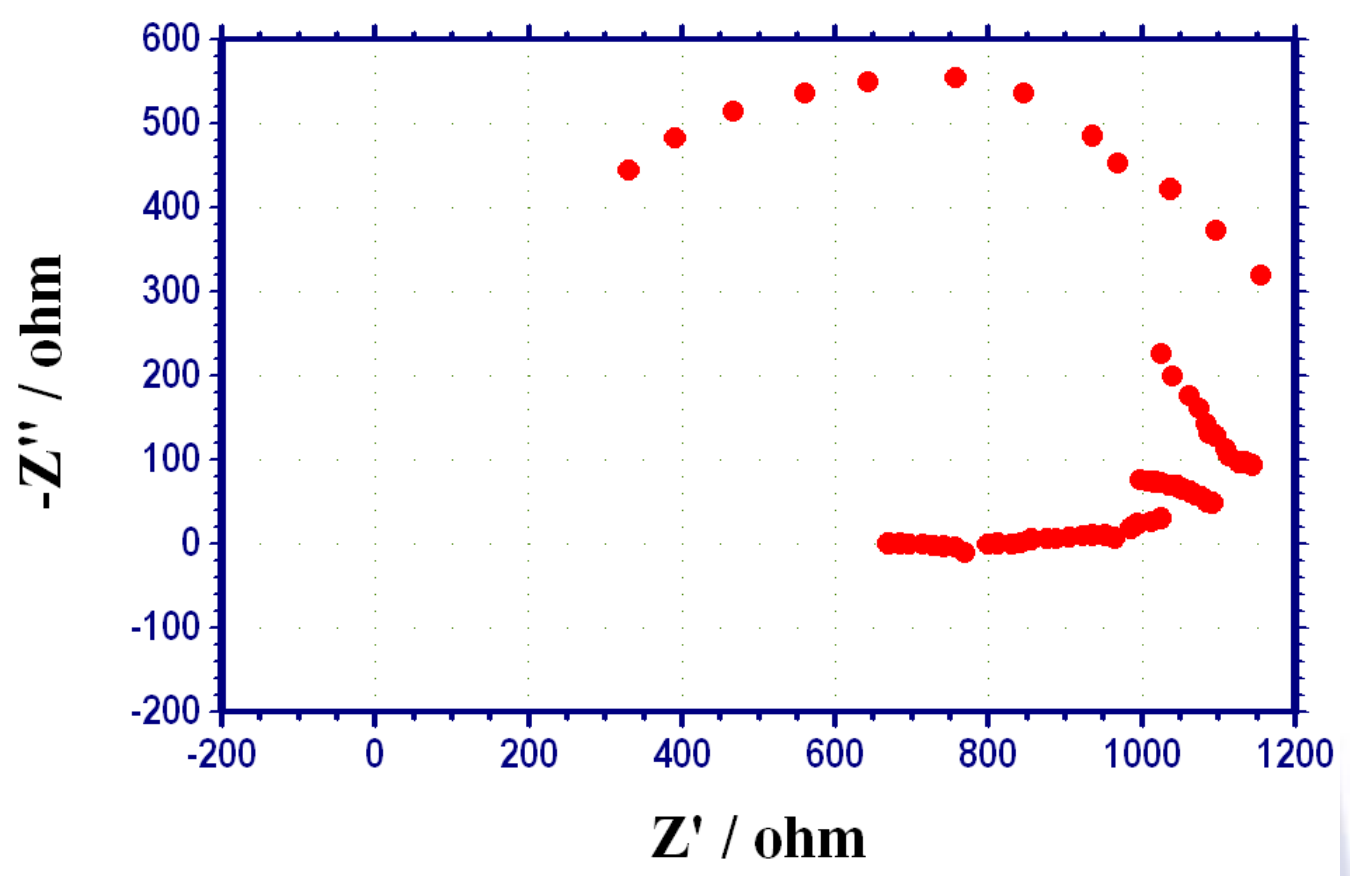

Fig.6: AC impedance spectrum of MS immersed in artificial tear solution (Nyquist Plot)

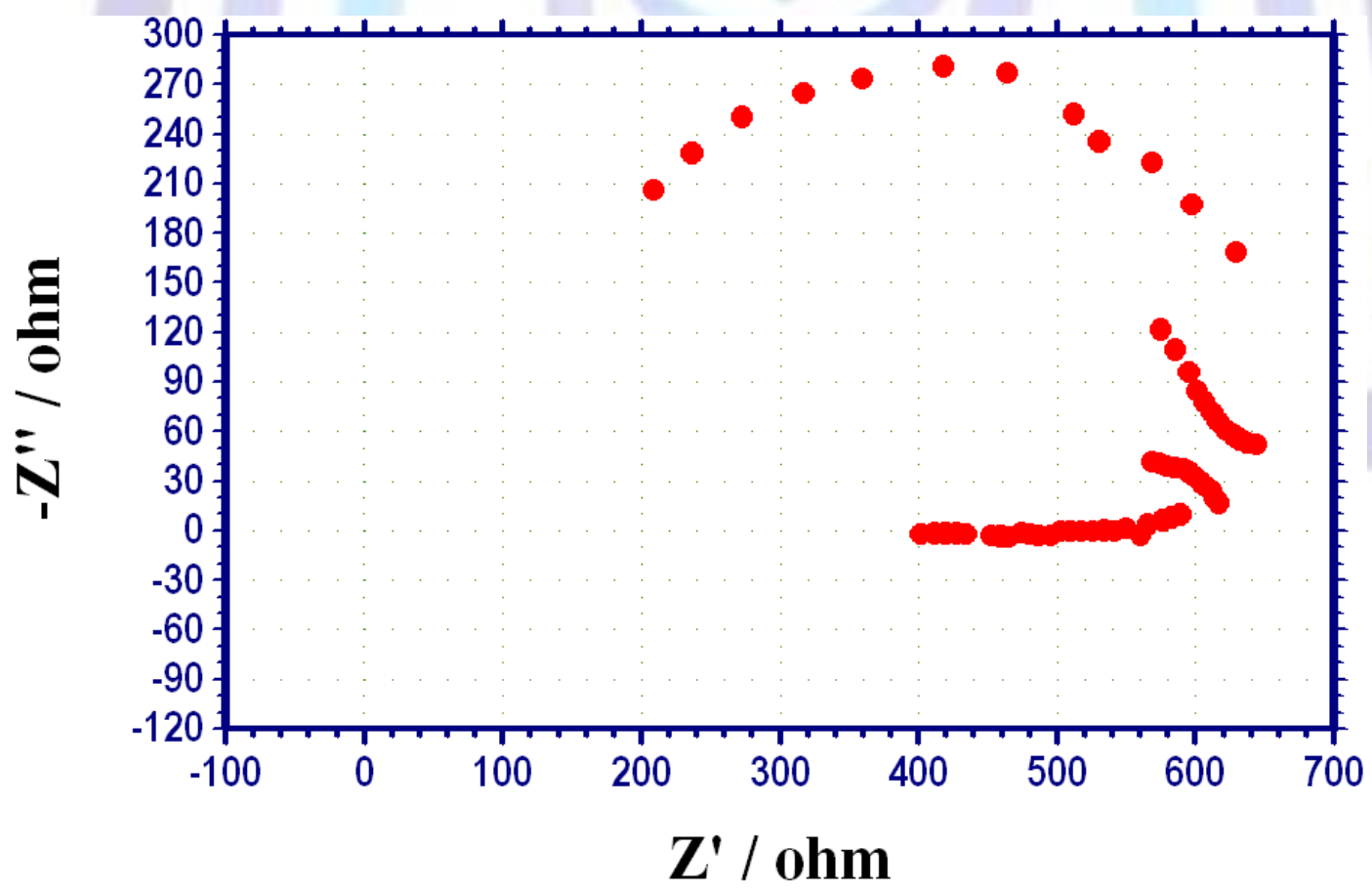

Fig.7: AC impedance spectrum of MS-Zn immersed in artificial tear solution (Nyquist Plot) 


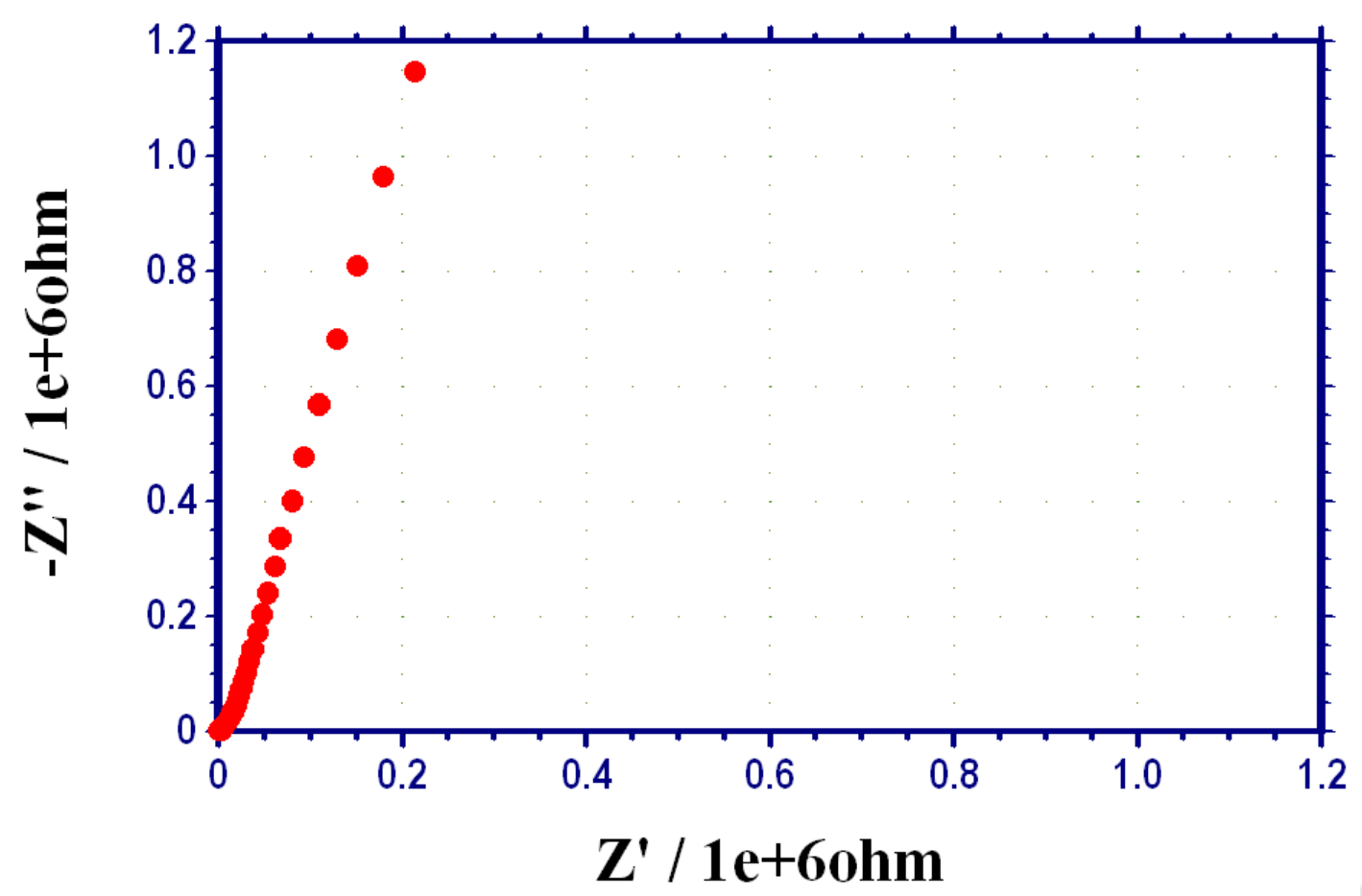

Fig.8: AC impedance spectrum of Ni-Cr immersed in artificial tear solution (Nyquist Plot)

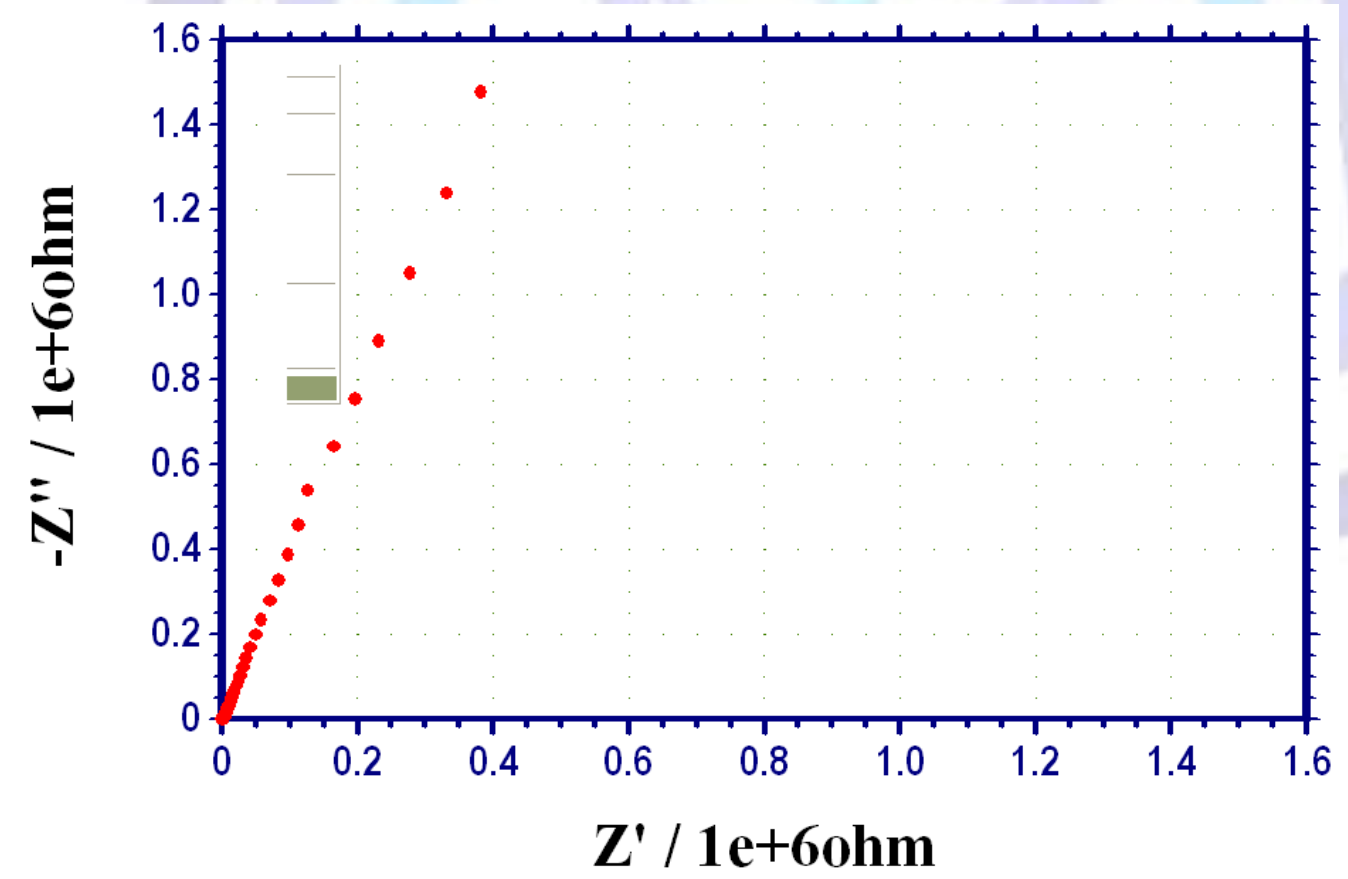

Fig.9: AC impedance spectrum of $\mathrm{Ni}-\mathrm{Ti}$ super elastic immersed in artificial tear solution (Nyquist Plot) 


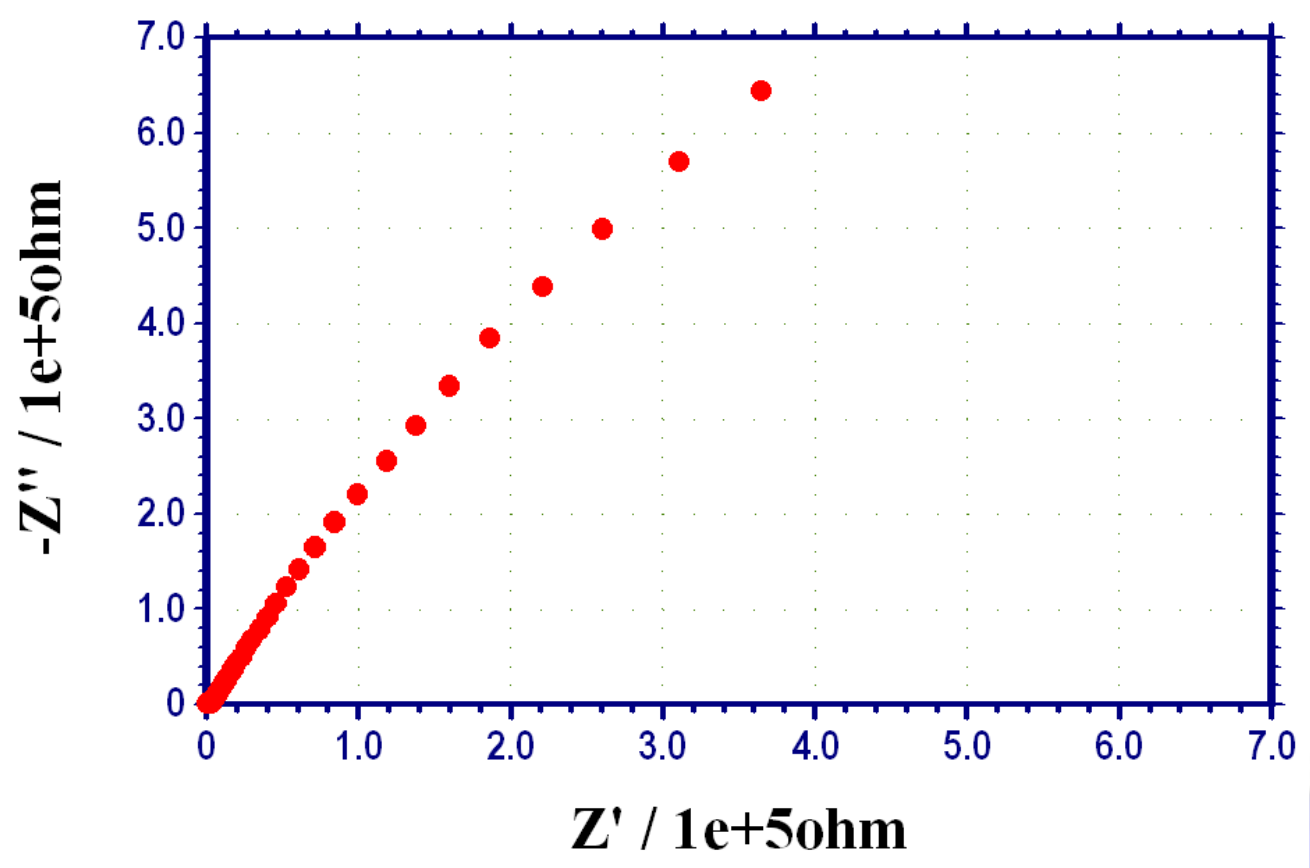

Fig.10: AC impedance spectrum of SS 316 immersed in artificial tear solution (Nyquist Plot)

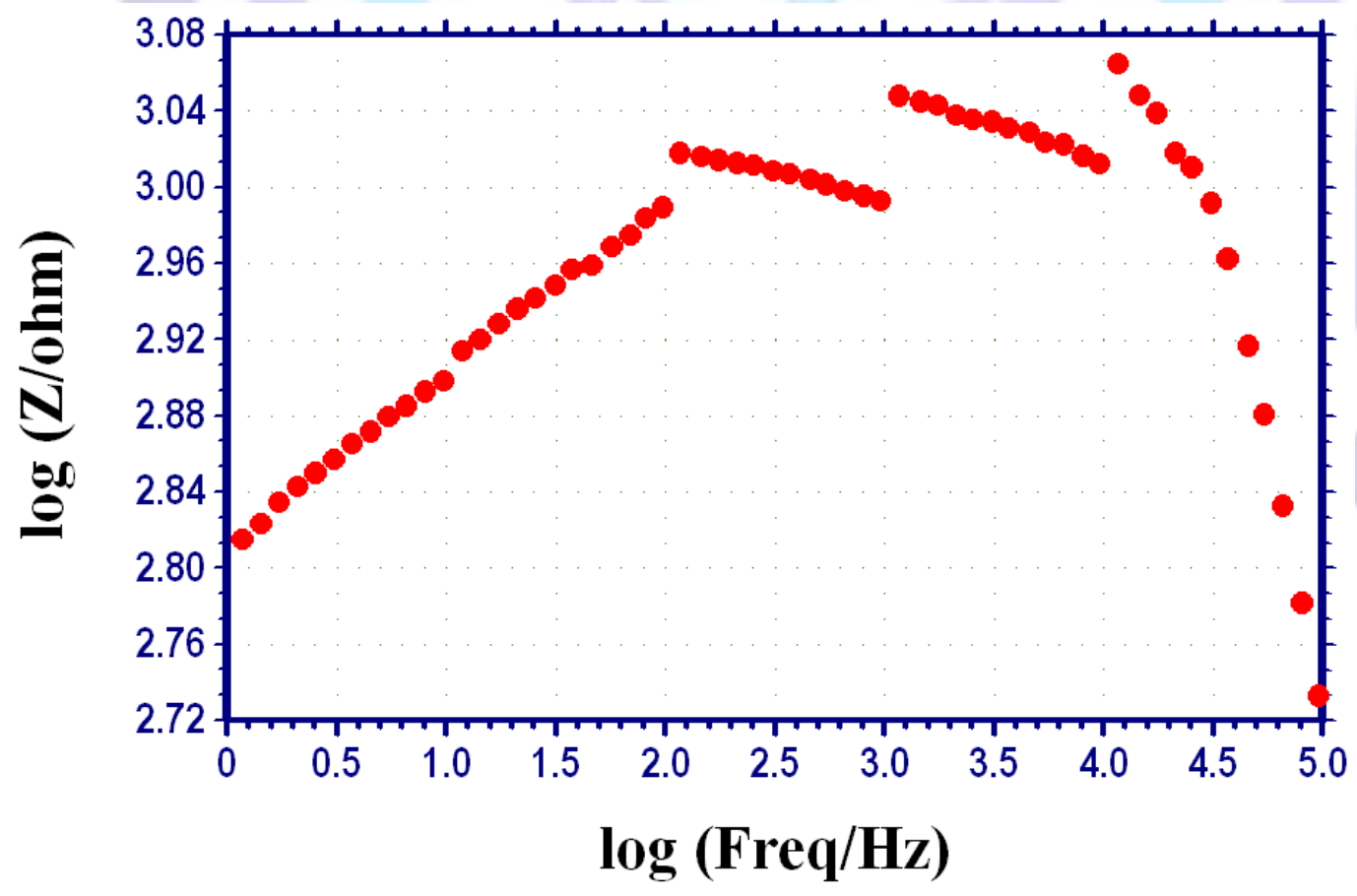

Fig.11: Impedance-Bode plot of MS in artificial tear solution 


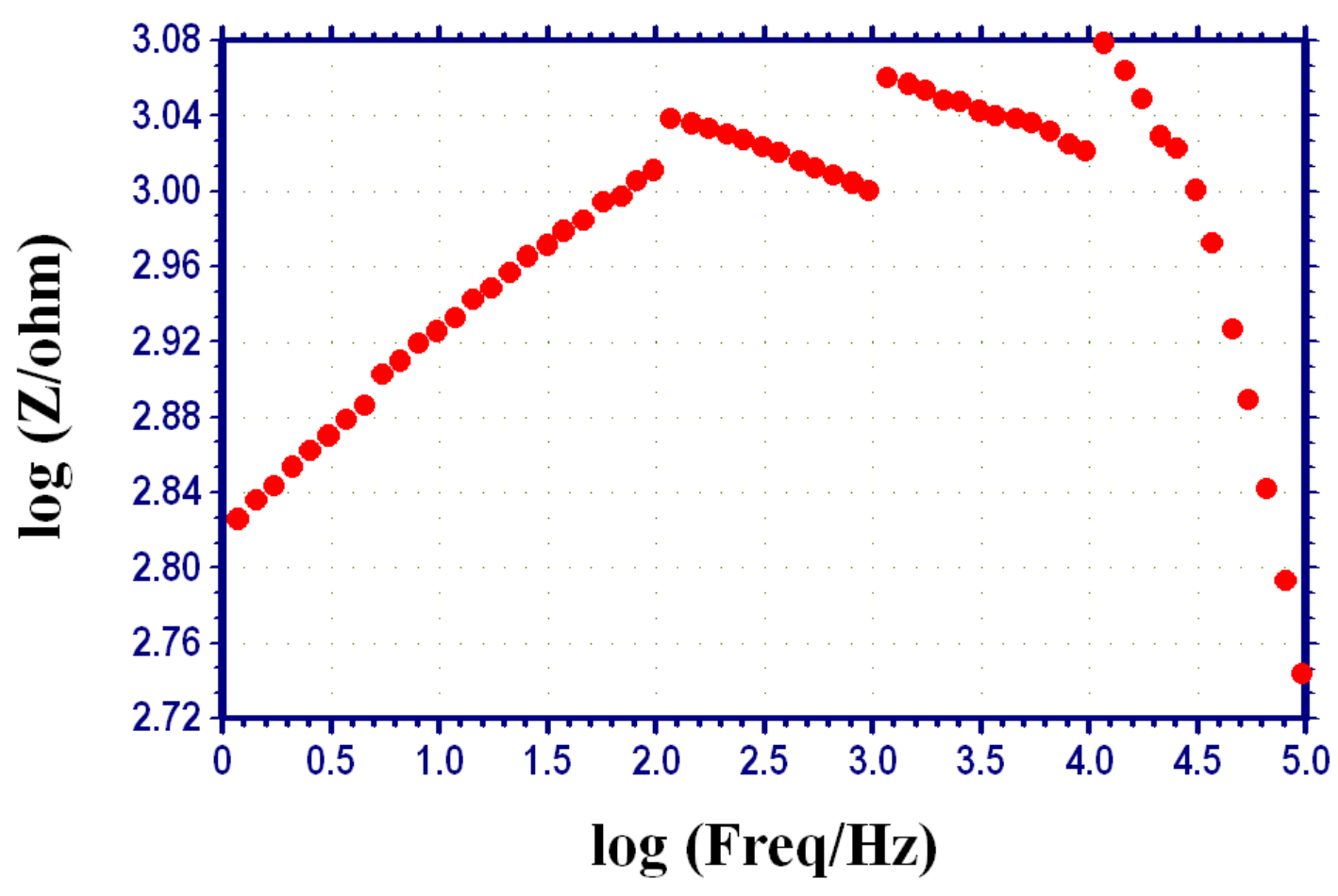

Fig.12: Impedance-Bode plot of MS-Zn in artificial tear solution

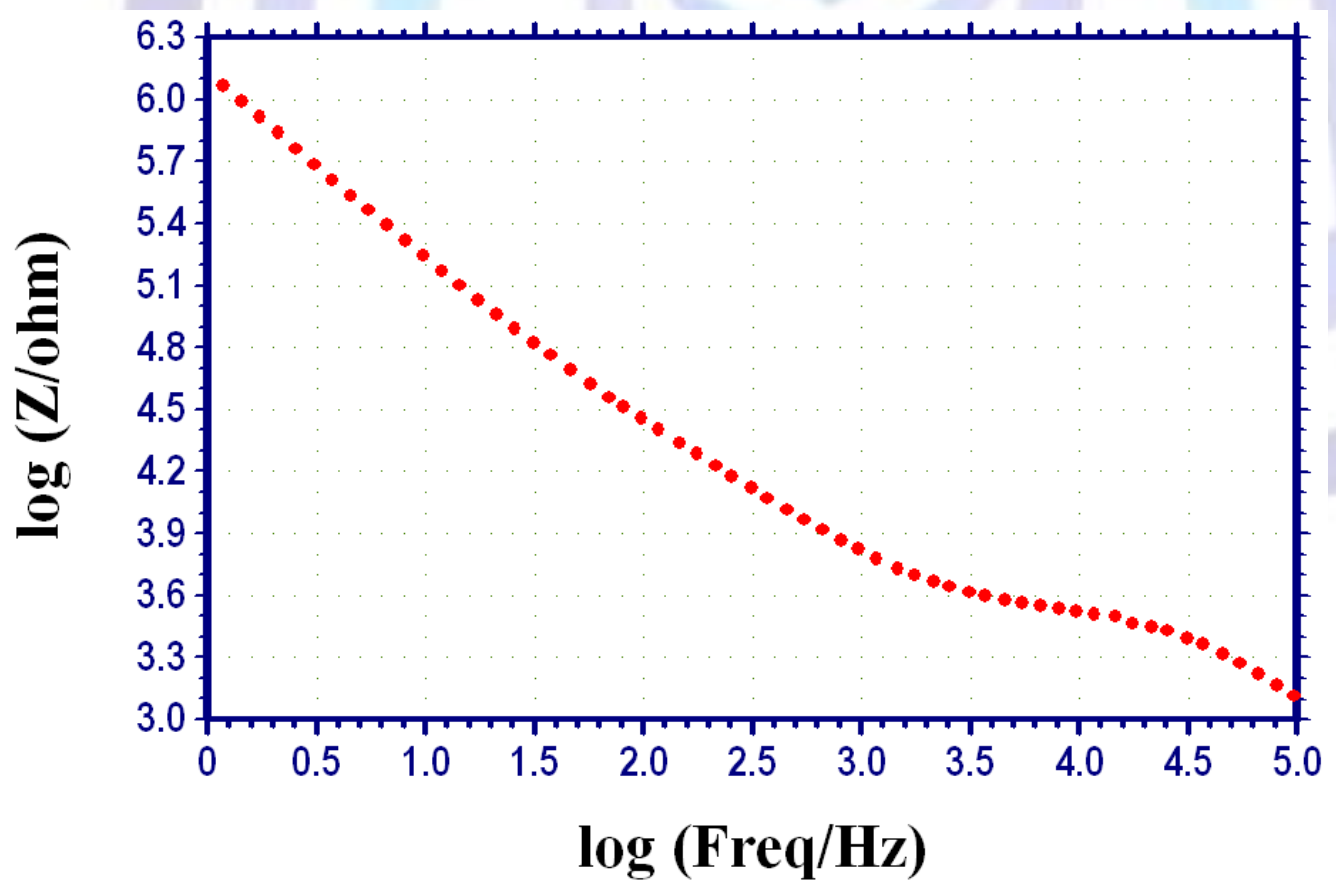

Fig.13: Impedance-Bode plot of $\mathrm{Ni}-\mathrm{Cr}$ in artificial tear solution 

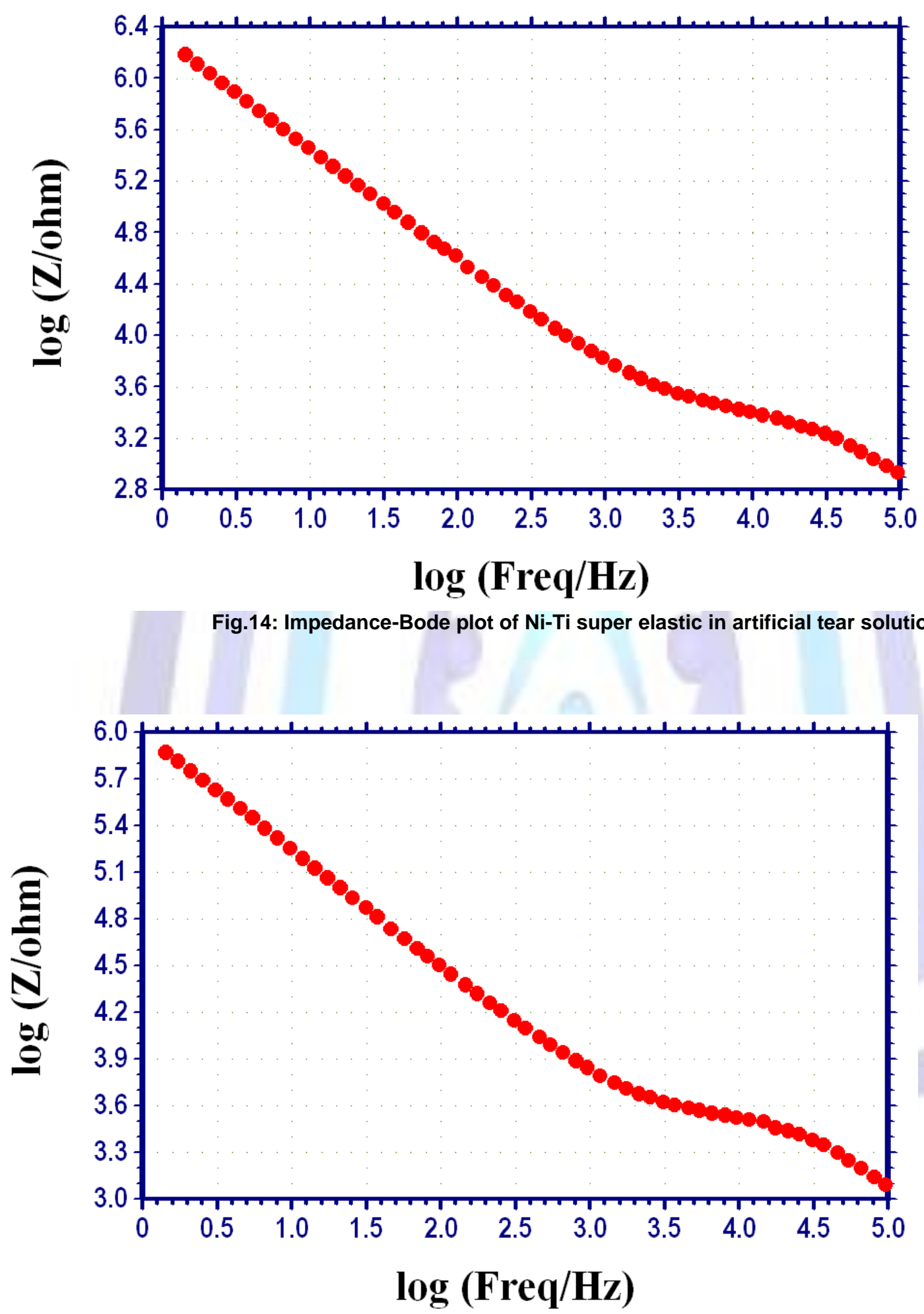

Fig.15: Impedance-Bode plot of SS $316 \mathrm{~L}$ in artificial tear solution 


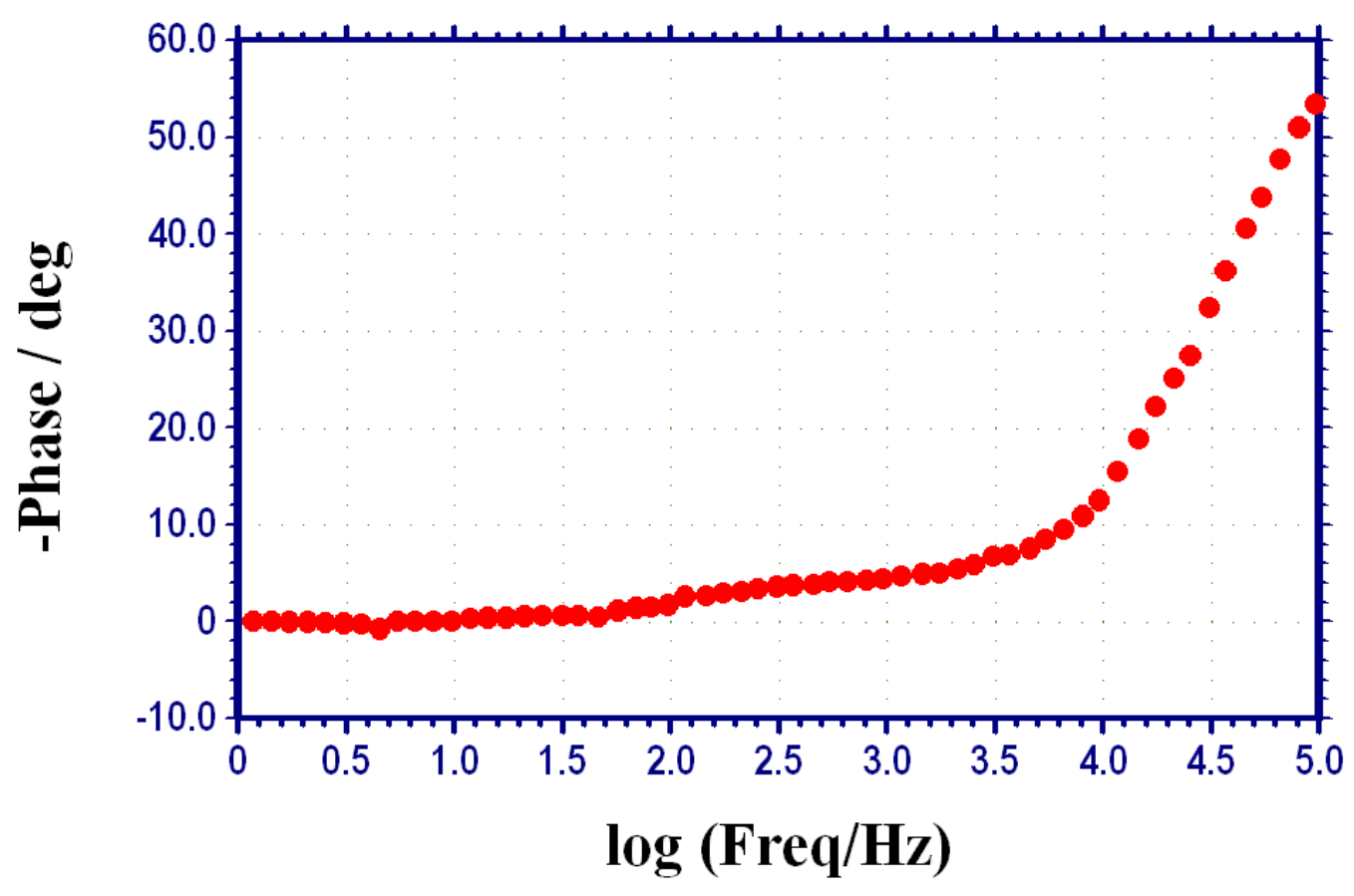

Fig.16: Phase-Bode plot of MS immersed in artificial tear solution

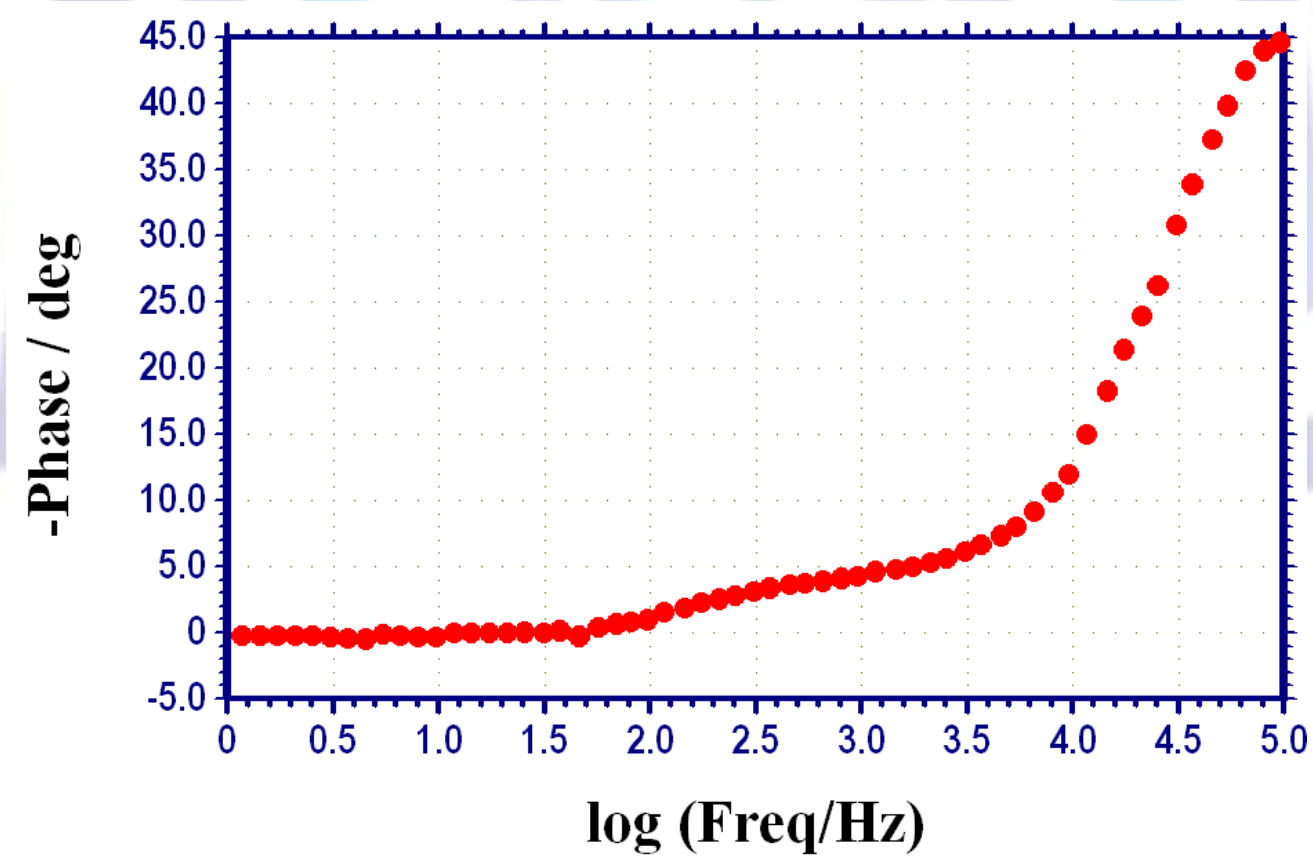

Fig.17: Phase-Bode plot of MS-Zn immersed in artificial tear solution 

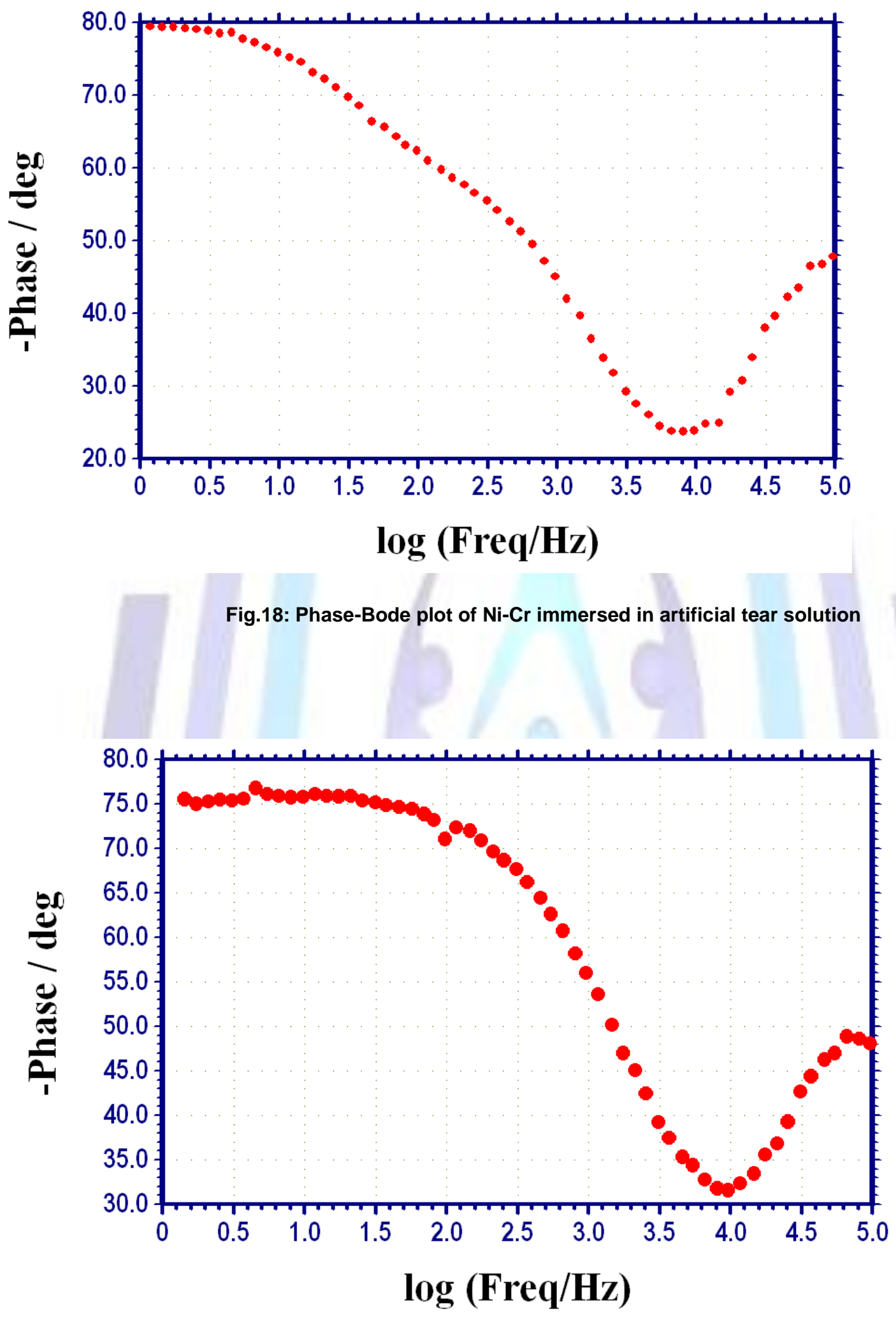

Fig.19: Phase-Bode plot of $\mathrm{Ni}-\mathrm{Ti}$ super elastic immersed in artificial tear solution 


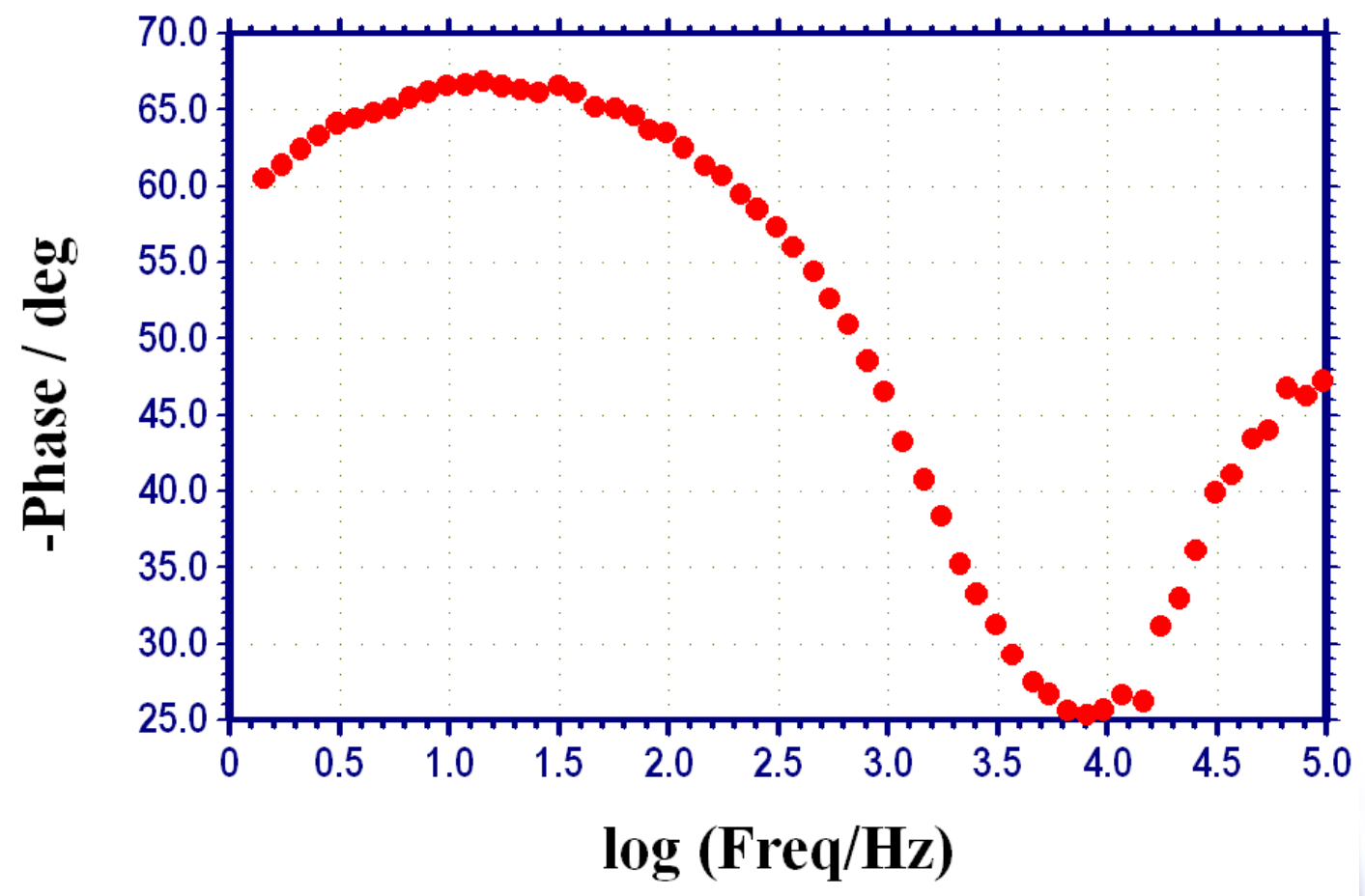

Fig.20: Phase-Bode plot of SS 316 L super elastic immersed in artificial tear solution

\section{Legends for Figures}

\section{Tafel}

Fig. 1 : Polarization curve of MS in artificial tear solution

Fig.2 : Polarization curve of MS-Zn in artificial tear solution

Fig.3 : Polarization curve of $\mathrm{Ni}-\mathrm{Cr}$ in artificial tear solution

Fig. 4 : Polarization curve of $\mathrm{Ni}-\mathrm{Ti}$ super elastic in artificial tear solution

Fig.5 : Polarization curve of SS $316 \mathrm{~L}$ super elastic in artificial tear solution

\section{Nyquist}

Fig.6 : AC impedance spectrum of MS immersed in artificial tear solution (Nyquist Plot)

Fig.7 : AC impedance spectrum of MS-Zn immersed in artificial tear solution (Nyquist Plot)

Fig.8: AC impedance spectrum of Ni-Cr immersed in artificial tear solution (Nyquist Plot)

Fig.9 : AC impedance spectrum of $\mathrm{Ni}$-Ti super elastic immersed in artificial tear solution (Nyquist Plot)

Fig.10 : AC impedance spectrum of SS 316L immersed in artificial tear solution (Nyquist Plot)

\section{Bode : Impedance - Bode}

Fig. 11 : Impedance-Bode plot of MS in artificial tear solution

Fig.12 : Impedance-Bode plot of MS-Zn in artificial tear solution

Fig.13 : Impedance-Bode plot of $\mathrm{Ni}-\mathrm{Cr}$ in artificial tear solution

Fig.14 : Impedance-Bode plot of $\mathrm{Ni}$-Ti super elastic in artificial tear solution

Fig.15 : Impedance-Bode plot of SS 316L in artificial tear solution 


\section{Phase - Bode}

Fig.16: Phase-Bode plot of MS immersed in artificial tear solution

Fig. 17 : Phase-Bode plot of MS-Zn immersed in artificial tear solution

Fig. 18 : Phase-Bode plot of $\mathrm{Ni}-\mathrm{Cr}$ immersed in artificial tear solution

Fig. 19 : Phase-Bode plot of $\mathrm{Ni}-\mathrm{Ti}$ super elastic immersed in artificial tear solution

Fig.20 : Phase-Bode plot of SS 316 Luper elastic immersed in artificial tear solution 